\title{
DISQUALIFICATION OF ATTORNEYS FOR REPRESENTING INTERESTS ADVERSE TO FORMER CLIENTS*
}

AN attorney may be disqualified 1 from litigation 2 if his participation would violate his ethical duty to a former client. ${ }^{3}$ For the last hundred years

\footnotetext{
*Consolidated Theatres, Inc. v. Warner Bros. Circuit Management Curp.: Is re Proceedings To Disqualify Robert E. Nickerson, 216 F.2d 920 (2d Cir. 1954).

1. Disqualification is used here to describe a court order directing an atturney to withdraw from a case. E.g., Brown v. Miller, 286 Fed. 994, 997 (D.C. Cir. 1923). It is usually granted in response to a motion by a party to the suit, c.g., T.C. Theatre Corp. $v$. Warner Bros. Pictures, Inc. 113 F. Supp. 265 (S.D.N.Y. 1953); but it may be issued on the court's own initiative, Porter v. Huber, 68 F. Supp. 132 (WV.D. Wash. 1946). An attorney need not be "of record" to be disqualified. Christian v. Waialus Agrieulture Co., 30 Hawaii 533 (1928). And grounds for disqualification prevent employment in the same case in any capacity. Steeley v. State, 17 Okla. Crim. 252, 262, 187 Pac. 821, 824 (1920) ; T.C. Theatre Corp. v. Warner Bros. Pictures, Inc., supra at 270. But apparently' only the former client has standing to move for opposing counsel's disqualification. Riley $v$. Bradley, 252 Ala. 282, 41 So. 2d 641 (1949). Cf. Fisher Studio, Inc. v. Law's, Inc., CCH TRADE REG. REP. (1954 Trade Cas.) \67725 (E.D.N.Y. 1954) (attorney disqualified as to defendants which he had never represented).

The English procedure is a bill in equity to enjoin the attorney's participation. Rakusen v. Ellis, [1912] 1 Ch. 831 (C.A.); Cholmondeley v. Clinton, 19 Ves. 201, 34 Eng. Rep. 515 (1815). This procedure is occasionally used in America. Alurphy v. Riggs, 238 MIich. 151, 213 N.W. 110 (1927).

The same questions of law can arise in a suit by a lawyer for his fee, c.g., Hunter v. Troup, 315 I11. 293, 146 N.E. 321 (1924), in an application for mandamus to require the trial court to allow participation by a specific attorney, c.g., Boyd v. Second Judicial District, $51 \mathrm{Nev} .264,274 \mathrm{Pac} 7$ (1929), or in an action to declare an attorney constructive trustee of property wrongfully acquired, c.g., Baker v. Humphrey, 101 U.S. 494 (1879).

A disqualification proceeding is not in the nature of a disciplinary proceeding. Brown v. Miller, supra at 997. The latter may impose disbarment, e.g., In re Boone, 83 Fed. 944 (C.C.N.D. Cal. 1897), suspension, c.g., In re Marron, 22 N.MI. 252, 160 Pac. 391 (1916), or censure, e.g., In re Mlaltby, 68 Ariz. 153, 202 P.2d 902 (1949). And these disciplinary proceedings require more formal procedures which are often regulated by statute. See Drinker, Legal Ethics 35-41 (1953); Philuips \& AICCoY, Co:rouct of Judges and Lawyers 10+18 (1952). See also Potts, Disbarment Procedure, 24 TEx. L. Rev. 161. (1946). But improper adverse representation can be the basis of such sanetions. In re Boone, supra; In re Cowdery, 69 Cal. 32, 10 Pac. 47 (18s6); In re O__ 73 Wis. 602, 42 N.W. 221 (1859).

2. This note deals only with disqualitication in civil cases. Various policies preuliar to criminal law make the grounds for disqualification of prosecutors less stringent than grounds for disqualification of counsel in civil cases. People v. Gerold, 265 III. 448, 107 N.E. 165 (1914). But of. State v. Lewis, 96 lowa 286, 65 N.W. 295 (1895). Sce also Comment, 60 YALE L.J. 626 (1952).

3. A former client may be a natural person or a legal person. People v. Hansun, 290 I11. 370, 125 N.E. 269 (1919) (school district); Boyd v. Secund Judicial District, 51. Nev. 264, 274 Pac. 7 (1929) (corporation). Where the atturney represented an asswciation, individual members of the association are not considered former clients. Almun v. American Carloading Corp., 312 Ill. App. 225, 38 N.E.2d 362 (1941). But if he was
} 
courts have been expanding the obligation owed former clients, broadening the area of employment prohibited to the attorney. ${ }^{4}$ At the same time, developments in legal practice have often made disqualification from even a small area of employment an increasingly severe sanction." The clash of these two trends in a number of recent cases suggests the necessity of reexamining the scope of the duty owed by an attorney to his former client. ${ }^{a}$

Disqualification rules were fashioned at common law to assure the public that any information confided in an attorney would never be disclosed or utilized adversely without the client's permission. ${ }^{7}$ Such a guaranty was

hired to represent several individuals who maintained they were partners, each individual is a former client though each might be found to have waived the right to distualify because of joint disclosure. Croce v. Superior Court, 21 Cal. App. 2d 18, 68 P.2d 369 (1937). A director of a corporation is not the former client of an attorney who represented that corporation. Bent v. Priest, 10 Mo. App. 543 (1881); Ferguson v. Alexander, 122 S.W.2d 1079 (Tex. Civ. App. 1938).

The interests of a former client continue after the client's death. Federal Trust Co. v. Damron, 124 Neb. 655, 247 N.W. 589 (1933). But a former client's interests do not include the interests of other members of his family. Harvey v. Harvey, 202 Wis. 553, 231 N.W. 580 (1930). And the interests of a predecessor corporation may not include those of its successor corporations. T.C. Theatre Corp. v. Warner Bros. Pictures, Inc., 113 F. Supp. 265 (S.D.N.Y. 1953).

4. See text at notes 9-20 infra.

The extent of an attorney's obligation to a former client is to be found in statutes regulating the conduct of the bar, e.g., CAL. Bus. \& PRof. CoDE $\$ 6068$ (1951); statutes prescribing the oath of an attorney, e.g., PA. Stat. Ans. tit. 17, \&1603 (1930); Axtemcan Bar Association, Canons of Professional Ethics, espec. Canons 6 and 37 (1947) (hereinafter cited as CANows); and the common law, c.g., Henry v. Raimam, $25 \mathrm{~Pa} .354$ (1855). In addition the attorney has an obligation to his new client. If the conflicting loyalties of the attorney to his former and present clients threaten to impair his proper representation of the new client, he will be disqualified. Hunter v. Troup, 315 I1l. 293, 302-03, 146 N.E. 321, 324 (1924) (dictum) ; Strong v. International Building, Loan and Investment Union, 183 Ill. 97, 102, 55 N.E. 675, 676-77 (1899) (same).

5. See text at notes 53-55 infra.

No statistical survey has been made to determine the number of lawyers or law firms devoted to specialized fields of law. But an awareness of lawyer specialization and latw firm departmentalization is indicated in Blausters, The Axertcan Lawyer 41.63 (1954). And representation of large corporate clients by these firms is shown in 2 Swaine, The Cravath Firm 712-15 (1948). The Swaine book also indicates the trend towards corporate mergers and law firm specialization.

6. Consolidated Theatres, Inc. v. Warner Bros. Circuit Management Corp. : In re Proceedings to Disqualify Robert E. Nickerson, 216 F.2d 920 (2d Cir. 1954) ; Fisher Studio, Inc. v. Loew's, Inc., CCH TrADE REg. Rep. (1954 Trade Cas.) I 67725 (E.D.N.Y. 1954); T.C. Theatre Corp. v. Warner Bros. Pictures, Inc., 113 F. Supp. 265 (S.D.N.Y. 1953).

7. In re Boone, 83 Fed. 944 (C.C.N.D. Cal. 1897) ; Kluht v. Mitchell, 199 Iowa 1.163, 199 N.W. 294 (1924); Hatch v. Fogarty, 40 How. 492 (N.Y. 1871).

Waiver by the client of the right to disqualify is operative and is usually the attorney's chief defense. E.g., Gottwals v. Rencher, 60 Nev. 35, 98 P.2d 481 (1940). The waiver may either be express, e.g., Wojahn v. Faul, 64 N.W.2d 140 (Minn. 1954), or implied, e.g., Harvey v. Harvey, 202 Wis. 553,231 N.W. 580 (1930). Courts are cxtremely reluctant to find waiver where it increases the former client's vulnerability to criminal liability. General Contract Purchase Corp. v. Armour, 125 F.2d 147 (5th Cir. 
deemed necessary to encourage maximum disclosure of all relevant facts, a prerequisite to adequate preparation of a client's case. ${ }^{8}$ At first, courts disqualified an attorney whenever he was retained ${ }^{3}$ against a former client who could prove that confidential information ${ }^{10}$ revealed to the lawyer during the previous representation would be useful in the present suit. ${ }^{11}$ But this placed too great a burden of proof on the former client because such facts were difficult to establish. ${ }^{12}$ Therefore, courts began to devise rigid evidentiary rules designed to assure the public that confidential disclosures would remain inviolate. The courts held that once a client confided any information in his attorney, the attorney was forever barred from utilizing such information even if the same information was later available to others from non-con-

1942). And waiver by a former client may not be operative where interests other than those of the named parties are involved. In re Themelis, $117 \mathrm{Vt}$. 19, 83 A.2d 507 (1951) (rights of children in a divorce action). It has been suggested that waiver is insufficient to discharge the attorney's obligations to the legal profession and to the administration of justice. Packer v. Rapoport, SS N.Y.S.2d 118 (Sup. Ct. 1949); Strong v. International Bldg., Loan and Inv. Union, 183 III. 97, 55 N.E. 675 (1899).

\&. Wilson v. State, 16 Ind. 392, 395 (1861). See W.H. TAFr, Etures ix Service 31-32 (1915) ; A.B.A., Canods of Professional and Judicial Etulcs, opinion 91 (1947). Cf. \& Wigarore, Evidence $\$ 2291$ (3d ed. 1940).

9. The prohibition of the common law is in terms of taling empluyment, Pierce v. Palmer, 31. R.I. 432, 77 At1. 201 (1910), and the breach of the duty occurs when the employment is begun or the retainer is accepted. In re Cowdery, 69 Cal. 32, 10 Pac. 47 (1886). Canows 6,36 and 37 , speak in terms of accepting empluyment or accepting retainers.

10. Information is communicated in confidence whether the elient relates it to his attorney, Wilson v. State, 16 Ind. 392 (1861), or gives him access to documents containing the information under circumstances which indicate that the information is not to be made public. T.C. Theatre Corp. v. Warner Bros. Pictures, Inc., 113 F. Supp. 205 (S.D.N.Y. 1953). Information secured by an attorney during an investigation made in preparation of his client's case is also considered confidential. Hovel v. Minneapnlis \& St. L. Ry., 165 Minn. 449, 206 N.W. 710 (1926). But cf. Skillman v. MIcDowell, 317 Ill. Apr. 85,45 N.E.2d 574 (1942).

"Confidential information" for the purpose of disqualification has been equated with "privileged communications." Croce v. Superior Court, 21 Cal. App. 2d 18, 68 P.2d 369 (1937). It has been suggested that disqualification is necessary to supplement the client's privilege to object to disclosure of confidential information. Watson v. W'atson, 171 Misc. 175, 11 N.Y.S.2d 537 (Sup. Ct. 1939). Other decisions indicate that "confidential information" for the purposes of disqualification is broader than "privileged communication." Packer v. Rapoport, 88 N.Y.S.2d 118 (Sup. Ct. 1949); Brown v. Miller, 286 Fed. 994 (D.C. Cir. 1923) ; Porter v. Huber, 68 F. Supp. 132, 135 (W.D. Wash. 1946) (dictum).

11. Johnson v. Marriott, 2 Cromp. \& Mr. 183, 149 Eng. Rep. 725 (1833); Bricheno v. Thorpe, Jac. 200, 37 Eng. Rep. 864 (1821) ; Cholmondeley v. Clinton, 19 Ves. 261, 34 Eng. Rep. 515 (1815).

12. Bricheno v. Thorpe, Jac. 200, 37 Eng. Rep. 864 (1821); Beer v. Ward, Jac. 77, 37 Eng. Rep. 779 (1821) ; Messenger v. Murphy, 33 Wash. 353, 74 Pae. 480 (1903). Disqualification attempts have failed in modern cases for the same reasun. Butler Brus. Development Co. v. Butler, 111. MIont. 329, 108 P.2d 1041 (1941). 
fidential sources. ${ }^{13}$ They disqualified an entire firm whenever grounds for disqualification existed against any partner. ${ }^{14}$ And they developed the doctrine that whenever a lawyer was employed against a former client in the "same matter" as the subject of the previous representation, ${ }^{15}$ the courts could infer the receipt of confidential information which might be useful in the present case and could disqualify the attorney involved. ${ }^{10}$

Even when there was no possibility that confidential information would be used against a former client, some courts disqualified attorneys who had represented that client in a related matter. ${ }^{17}$ These courts feared that unless they strictly enforced a duty of fidelity independent of the non-disclosure obligation, the public would not believe that attorneys were exercising their best efforts on behalf of their clients. ${ }^{18}$ If an attorney were allowed to attack the validity of a contract which he had previously drawn, many would believe that he had not faithfully served his former client. ${ }^{10}$ Therefore, some cotrrts

13. United States v. Bishop, $90 \mathrm{~F} .2 \mathrm{~d} 65$ (6th Cir. 1937) (information available in Veteran's Administration records) ; T.C. Theatre Corp. v. Warner Bros. Pictures, Inc., 113 F. Supp. 265 (S.D.N.Y. 1953) (findings of government antitrust litigation) ; Boyd v. Sccond Judicial District, 51 Nev. 264, 274 Pac. 7 (1929) (corporation's secrets known by now client as well as attorney); Watson v. Watson, 171 Misc. 175, 11 N.Y.S.2d 537 (Sup. Ct. 1939) (former client's bad character of public record).

14. Christian v. Waialua Agriculture Co., 30 Hawaii 533 (1928); In re Cowdery, 69 Cal. 32, 63, 10 Pac. 47, 65 (1886) (dictum).

15. See, e.g., In re Maltby, 68 Ariz. 153, 202 P.2d 902 (1949); Purdy v. Ernst, 93 Kan. 157, 143 Pac. 429 (1914); Gillett v. Gillett, 269 Mich. 364, 257 N.W. 719 (1934); In re Themelis, 117 Vt. 19, 83 A.2d 507 (1951).

A showing that subject matter involved in the present suit is the "same matter" as that involved in the previous representation may be made apparent by affidavits, Boyd v. Second Judicial District, 51 Nev. 264, 274 Pac. 7 (1929), pleadings, Brown v. Miller, 286 Fed. 994 (D.C. Cir. 1923), or testimony, People v. Gerold, 265 IIl. 448, 107 N.E. 165 (1914).

16. State v. Rocker, 130 Iowa 239, 106 N.W. 645 (1906); State v. Halstead, 73 Iowa 376,35 N.W. 457 (1887); Gauldin v. State, 11 Ga. 47 (1851).

17. Pierce v. Palmer, 31 R.I. 432, 448-49, 77 At1. 201, 208-09 (1910); In re Wilmarth, 42 S.D. 76, 87, 172 N.W. 921, 924 (1919); Barreda Corp. v. Ballenger, 116 S.W.2d 442, 448 (Tex. Civ. App. 1938) (dictum). See, generally, Drinker, LegdL Ethics 109 (1953) ; Thornton, Atrorneys At Law $\$ 174$ (1912). Cf. Weeks, AttorNEYS AND CounselLoRs AT LAW \& 271 (1892).

18. In re Maltby, 68 Ariz. 153, 202 P.2d 902 (1949); In re Cowdery, 69 Cal. 32, 35, 10 Pac. 47, 48 (1886) ; Hatch v. Fogerty, 40 How. 492, 500-01 (N.Y. 1871). Cf. Fairfield County Bar v. Taylor, 60 Conn. 11, 17, 22 Atl. 441, 443 (1891).

The courts have used the term fidelity to describe various obligations owed to former clients by their attorneys. In Henry v. Raiman, $25 \mathrm{~Pa} .354$ (1855), and in United States v. Costen, 38 Fed. 24 (C.C. Col. 1889), the courts discussed the duty of fidelity as if it were synonomous with the duty of non-disclosure. The duty of fidelity is used in this note to indicate an obligation of loyalty or faithfulness to the former client's interests which were the subject of the attorney's previous representation. This obligation exists apart from the duty to keep confidential information inviolate.

19. Wingilia v. Cushman, 241 Mich. 534, 217 N.W. 909 (1928). A similar situation existed in Federal Trust Co. v. Damron, 124 Neb. 655, 247 N.W. 589 (1933), where 
prohibited attorneys from opposing former clients whenewer the attorney had been previously consulted concerning the matter involved. ${ }^{20}$ Here, as well as when they were attempting to preserve the confidences of clients, courts were more interested in the public's impression of how these protective rules were operating than in their actual operation. ${ }^{21}$ For unless clients were convinced that the doctrines maintained the fidelity and secrecy of attorneys, the evils which the rules were designed to meet would continue.

In the recent case of Consolidated Theatres, Inc. v. Warner Bros. Circuit Management Corporation: In re Proceedings To Disqualify Robert E. Nickerson, ${ }^{22}$ an expansive construction of the ethical duty owed former clients would have meant disqualification of an attorney from his principal field of specialization. ${ }^{23}$ Nickerson, while an associate of a large New York law firm, helped represent several major motion picture distributing corporations in antitrust litigation including the Schine ${ }^{24}$ and Griffith ${ }^{25}$ suits. ${ }^{20}$ In both these cases the Government subpoenaed huge quantities of the distributors'

the court refused to allow an attorney to attack a trust arrangement set up in reliance on his advice.

20. In re Boone, 83 Fed 944 (C.C.N.D. Cal. 1897) (validity of patents); Wutchumna Water Co. v. Bailey, 216 Cal. 564, 15 P.2d 505 (1932) (settlement agreement of prior suit); People v. Hanson, 290 I1l. 370, 125 N.E. 268 (1919) (legality of a school board). But cf. Alliance Trust Co. v. Hubbard, 87 Ore. 669, 171 Pac. 550 (1918), where an attorney who drafted a mortgage for a client was subsequently allowed to represent the mortgagee in a suit on the mortgage against the attorney's former client.

Similar considerations led to the enactment of a federal statute, 62 Srar. 6\$3 (1948), as amended, 18 U.S.C. $\$ 284$ (1952), which precludes prosecution of any claim against the United States involving any subject matter with which a former government employee was directly connected through employment or performance of duty. Cf. Alasox, BRisivas-A FREE MLAN's LIFE 224-29 (1946), where the author describes the controversy surrounding Brandeis' switch in the United Shoe Machincry cases.

21. In re Maltby, 68 Ariz. 153, 155, 202 P.2d 902, 903 (1949); Fairficld County Bar v. Taylor, 60 Conn 11, 22 Atl. 441 (1890); In re Cowdery, 69 Cal. 32, 10 Pac 47 (1886). See also A.B.A., Canons of Professional and Judictal. Ethics, opinion 71 (1947); N.Y. County LawYers' Assoctatton Yearbook 135-37 (1922).

22. 216 F.2d 920 (2d Cir. 1954) (hereinafter cited as In re Nickerson), 40 A.B.A.J. 1086 (1954).

23. Nickerson specialized in motion picture antitrust law. The Special Master found that of 18,076 recorded hours of work by Nickerson while in the employment of the firm of Dwight, Royall, Harris, Koegel and Caskey between August 1942 and October 1950, over $80 \%$ was devoted to motion picture antitrust matters. Special Master's Report, pp. 3-4, In re Nickerson, 216 F.2d 920 (2d Cir. 1954).

A Special Master was appointed below to hear evidence on the proceedings to disqualify Nickerson. His findings and opinions were adopted by the district court, In re Nickerson, 1953 Trade Cas. If 67543 (S.D.N.Y. 1953). The Mfaster's report was not officially or unofficially reported, but it was printed by Appellant as part of his bricf and will hereinafter be cited as Master's Report.

24. Schine Chain Theatres, Inc. v. United States, 334 U.S. 110 (194\$).

25. United States v. Griffith, 334 U.S. 100 (194S).

26. Of the eleven corporations involved in the Consolidated case, the firm with which Nickerson had previously been associated had never represented three. Brici fur Appellant-Respondent, p. 48, In re Nickerson, 216 F.2d 920 (2d Cir. 1954) (hereinaiter 
documents in an effort to establish the existence among all the major distributors and several large exhibitor chains of a conspiracy to monopolize and restrain the exhibition of first run films in certain areas. ${ }^{27}$ Nickerson's job was to assist counsel of record to obtain judicial findings of fact that would make more difficult any subsequent private litigation against the distributors which his firm represented. ${ }^{28}$ For this purpose he was given complete access to the records and files of these clients. ${ }^{20}$ Two years after the Supreme Court decisions in Schine and Griffith, Nickerson left the large law firm and formed a partnership. ${ }^{30}$ This new firm filed a complaint on behalf of a Worcester, Massachusetts, exhibitor, charging a conspiracy among these distributors $^{31}$ and others ${ }^{32}$ to monopolize and restrain the exhibition of first run films in fifteen major cities including Worcester. None of these cities had been involved in Schine or Griffith, but the specific trade practices alleged to result from an unlawful conspiracy were identical to the ones litigated in those cases. ${ }^{33}$ All defendants moved ${ }^{34}$ to disqualify Nickerson and his firm

cited as Brief for Appellant). There was no proof below that the firm had ever represented two others. Ibid. And of the six remaining corporations the Dwight firm served as general counsel to only Twentieth Century-Fox during the entire period of Nickerson's employment. Id. at 3 . The five remaining corporations occasionally retained the Dwight firm. They were Loew's, Inc., Paramount Pictures, Inc., RKO Radio Pictures, Inc., United Artists Corporation, and Warner Bros. Pictures, Inc. These five were referred to by the Appellant as the "group." Id. at 54. Nickerson participated in thrce cases in which the firm represented the "group" as well as Fox. In addition Nickerson devoted over 1500 hours to work involved in United States v. Paramount Pictures, Inc, 334 U.S. 131 (1948), in which the Dwight firm was retained only by Fox and its sulbsidiaries. Brief for Appellant, app. p. 14.

27. In re Nickerson, 216 F.2d 920, 922, 923 (2d Cir. 1954).

28. Id. at 922 .

29. Ibid.

30. The Schine and Griffith cases were decided by the Supreme Court on May 3, 1948. The Griffith case was relitigated on remand and decision was pending in 1950. Nickerson left the Dwight firm on October 1,1950 . The complaint in the Consolidated suit was filed on April 6, 1951.

31. Fox and the "group." See note 26 supra.

32. Warner Bros. Circuit Management Corporation, Universal Pictures Company, Inc., United Paramount Theatres, Inc., Radio-Keith-Orpheum Corporation, Paramount Pictures Corporation.

33. The practices alleged in the complaint were those found to have existed among the distributors and privileged exhibitors in United States v. Paramount Pictures, Inc,, 334 U.S. 131 (1948). Many of the same practices had been litigated in the Schinc and Griffith cases in which Nickerson also participated. These practices included the monopolization and restraint of the exhibition of first run quality films in violation of the Sherman Act, 26 STAT. 209 (1890), as amended, 15 U.S.C. $\$ \$ 1-2$ (1952), by means of master agreements whereby the favored exhibitors were permitted to utilize their mass buying power to deprive competitors of first and subsequent runs and were granted exclusive privileges in the exhibition of films. Compare Complaint, pp. 20-29, In re Nickerson, 1953 Trade Cas. If 67543 (S.D.N.Y. 1953) with Schine Chain Theatres, Inc. v. United States, 334 U.S. 110, 113-16 (1948) and with United States v. Griffith, 334 U.S. 100, 101-04 (1948).

The complaint differs from the Schine and Griffith cases in that additional conspira- 
for breach of his ethical duties as now embodied in Canon $\mathrm{Six}^{35}$ of the Canons of Professional Ethics of The American Bar Association. ${ }^{30}$

tors are named and the practices are alleged to have occurred in various major cities throughout the United States rather than in restricted geographic areas.

34. Twentieth Century-For and Paramount Pictures, Inc moved to disqualify Niclserson on May 15, 1951. On January 29, 1953, after hearings before the Special Master, the nine other defendants appeared in the proceedings. Brief for Appellant, pp. 11-13.

35. CANON 6 reads in part as follows:

"The obligation to represent the client with undivided fidelity and not to divulge his secrets or confidences forbids also the subsequent acceptance of retainers or employment from others in matters adversely affecting any interest of the client with respect to which confidence has been reposed."

In Nickerson the Second Circuit held that Cavon 6 was properly applieable to the facts of that case. In re Nickerson, 216 F.2d 920, 924 (2d Cir. 1954). The Canun was based on $\$ \$ 21$ and 22 of the Alabama State Bar Association Code of Ethies. 31 A.B.A. REP. 698-99 (1907). Alabama $\$ 22$ states: "The duty not to divulge the secrets of clients extends further than mere silence by the attorney, and forbids accepting retainers . . . [in certain matters] about which the confidence was reposed. When the secrets or confidence of a former client may be availed of ... [possibly to harm the former elient in a later suit] the attorney cannot appear in such cause without the consent of his furmer client." Prior to 1908 , eight state associations adopted the Alabama rule verbatim. Id. at 699 . The A.B.A. version inserts the phrase "the obligation to represent the client with undivided fidelity" in addition to the duty not to divulge information. The draftsman's intent seems to have been the creation of two duties: (1) not to divulge certain information, and (2) the obligation of fidelity. In terms of the Canon both duties enjuin attorneys from accepting certain types of future employment. See Dri:irers, Lecilt. EтHICs 109 (1953); 26 RockY Mir. L. Rev. 195 (1954). See also the cross-reference of CANon 6 to Hoffman's Resolution VIII provided by the A.B.A. committee that draited the Canons. 33 A.B.A. REP. 586 (1908). This Resolution prohibits talsing employment against a former client in the same "cause" and nowhere mentions secrets ar confidences. 31. A.B.A. REP. 719 (1907).

Since 1924 the Committee on Professional Ethics and Grievances of the Ameriean Bar Association has published official advisory opinions on proper professional conduct. Of the 287 published opinions 274 appear in A.B.A, C.avons of Profrssional And Judictal ETHICs (1947). The remaining appear in the A.B.A. Journals. An additional 300 rulings were authorized for publication in 1952. DRINkER, op. cif. sispra at 31 . Similar advisory opinions have been published by the Ethics Committee of the Xew York: County Lawyer's Association, The Association of the Bar of New York, and the Michigan Bar Association. Several other states and local bar associations were contemplating publication in 1952. Id. at 31, 32. For a classification of committee opinions construing Carion 6, see $i d$. at 103-30, 298-99.

36. Rule 5(c) incorporating the Canons of Professional Ethics of the American Bar Association as the official rules of the court "was adopted by the Judges of the United States District Courts for the Southern and Eastern Districts of New York pursuant to an order entered February 6,1952 with effective date at the beginning of business on March 1, 1952." Letter from Clerk of the Southern District Court to the Yole Los: Joumal, Oct. 29, 1954, on file in Yale Law Library; 16 Fed. RuLes Senv. St8 (1952).

As of 1952, 25 states had bar associations established on an integrated basis. In these states, membership in the state bar association is a prerequisite to practice. All these states have a code of professional ethics promulgated by the state supreme court (in 15), by action of the state bar association (7), by statute (2), or by otiner mearis. Although some of the codes differ in wording their general effect is similar. See PulL- 
The Second Circuit affirmed the district court's disqualification of Nickerson ${ }^{37}$ as to those defendants which had retained the New York firm for antitrust matters during the time Nickerson was employed by that firm. ${ }^{\text {s }}$ The court feared that if Nickerson were allowed to continue in the case he might be able to utilize confidential information acquired during his previous relationship with the five named defendants. It inferred that Nickerson had received confidential information because of his access to the defendints' files during the Schine and Griffith litigation. And, due to the similarity in sub-

Lips \& McCoy, Conduct of Judges and Lawyers 13-14 (1952); Blaustein \& Poktek, The American Lawyer 240 (1954); Drunker, op. cit. supra note 35, at 20-21. For a brief but fully explanatory article on integration, see Wicker, Integrated Bars, 21 T'EN. L. REv. 708 (1951).

In the other 23 states, and the District of Columbia, which have voluntary bar associations, three have codes adopted by the state supreme court, fifteen have codes adopted by the state bar association, and two states have otherwise promulgated their codes. Phillips \& McCox, op. cit. supra at 15; Blaustein \& Porter, op. cit. supra at 241.

The Canons have been occasionally cited by the courts but until recently no decision attempted to construe their text. Usually courts assumed that they restated generally accepted ethical standards. E.g., In re Maltby, 68 Ariz. 153, 202 P.2d 902 (1949); Matter of Cohen, 261 Mass. 484, 487, 159 N.E. 495, 496-97 (1928). The first judicial construction of Canon 6 occurred in T.C. Theatre Corp. v. Warner Bros. Pictures, Inc., 113 F. Supp. 265 (S.D.N.Y. 1953).

37. The original application sought disqualification of Nickerson's new partner William Gold as well as of Nickerson and the firm. Memorandum on Behalf of Twentieth Century-Fox and Paramount Pictures, p. 1, In re Nickerson, 216 F.2d 920 (2d Cir. 1954). The Master found that Gold was disqualified "on the principle that this disqualification of his partner, Nickerson, necessarily disqualifies the firm." Master's Report, p. 25. See note 14 supra. But Gold's qualifications were stipulated to be outside the scope of the proceeding when it came before the district court and that court confirmed disqualification only as to Nickerson and the firm of Gold and Nickerson. In re Nickerson, 1953 Trade Cas. $\int 67543$ (S.D.N.Y. 1953). This disqualification was affirmed by the Second Circuit. In re Nickerson, 216 F.2d 920, 928 (2d Cir. 1954).

38. Nickerson was disqualified as to five defendants. They included Fox and the "group" as defined in note 26 supra, with the exception of United Artists Corporation. In re Nickerson, 216 F.2d 920, 928 (2d Cir. 1954). United Artists retained the Dwight firm in the Griffith and a related case but did not in the Schine case. Brief for Appellant, app. pp. 12-13. Either the omission was a clerical error or the Schinc representation was considered determinative. Since the Schine and Griffith cases involved substantially related matters, the latter hypothesis seems unjustified.

Upon Nickerson's disqualification as to the "group" it became necessary for him to withdraw from the entire suit because, as a practical matter, it would have been impossible to prove a conspiracy among only those distributors which had never been represented by the Dwight firm. The partnership of Gold \& Nickerson was dissolved on March 31, 1953, as a result of the Master's decision, leaving Gold free to continue in the case. Brief for Appellant, p. 13. In Fisher Studio, Inc. v. Loew's, Inc, CCH Tradv REg. Rep. (1955 Trade Cas.) $\int 67990$ (E.D.N.Y. 1955), the court held that where $A$ and the firm of $A$ and $B$ have been disqualified from representing plaintiff exhibitor in a treblc damages private antitrust action due to $A$ 's previous relationship with some of the defendents, attorney $B$ and his new firm of $B$ and $C$ are qualified to continue the action on behalf of the plaintiff as the prior disqualification related only to $A$ inclividually and to the firm of $A$ and $B$. Attorney $B$ in this case is in the same position as Gold in Consolidated. 
ject matter between those cases and the present one, ${ }^{30}$ the court concluded that this information would be useful. ${ }^{40}$ Thus, it found a basis for disqualifying Nickerson by adopting the common law device of inferring the receipt of useful confidential information from the similarity in subject matter of past and present representations. ${ }^{41}$

The court refused, however, to adopt the common law fidelity rule as a reason for precluding Nickerson's participation in Consolidated. The district court had applied the fidelity rule in its broadest aspect: it categorized past controversies over the existence of a conspiracy in terms of distributor as against exhibitor interests and held that since Nickerson had spent eight years attempting to prove that there had been no conspiracy among the distributors he could not now attempt to prove the contrary.2 Therefore, the district court disqualified Nickerson against all the defendants in Consolidated. The Second Circuit rejected this approach and refused to bar Nickerson from representing exhibitors against distributors other than those which had been represented by Nickerson's employer in Schine and Griffith.13

The Court of Appeals took a moderate position concerning the attorney's

39. See notes 15 and 33 supra.

40. In re Nickerson, 216 F.2d 920, 924-25 (2d Cir. 1954).

41. See notes 15 and 16 supra and accompanying text.

The defendant-petitioners originally based their motion to disqualify Nickerson on the ethical obligations implicit in Canons 6 and 37 and the common law. Their contentions were accepted by the Master. Master's Report, pp. 2, 15-16. In his report no single standard was utilized as a basis for the decision.

Canon 37 provides in part: "It is the duty of a lawyer to preserve his client's confidences. This duty outlasts the lawyer's employment, and extends as well to his cmployees; and neither of them should accept employment which involves or may involve the disclosure or use of these confidences either for private advantage of the lawyer ur his employee ...." The obligations described are similar to those specified in paragraph 3 of Canon 6. See note 35 supra. Nickerson argued that only Caxos 37 was applicable to the proceedings because CAxos 6 requires a personal relationship in which the client directly reposes confidence in the skill of the attorney, and since he had mercly been an employee of the Dwight firm, no confidence had been reposed in him. Brief for Appellant, pp. 37-41. This argument was expressly rejected by the Second Circuit. In re Nickerson, 216 F.2d 920, 927 (2d Cir. 1954).

42. Indeed, the Mfaster may have intended to disqualify Nickerson frum ever bringing antitrust actions against any movie distributor in any part of the country. He said: "Nickerson's counsel apparently assumes that each of the anti-trust cases in which he participated were in local areas and that the facts ... could have no bearing on an entirely different area, Worcester, Massachusetts. .... These cases . . . do not . . . represent local trials involving local issues. They are part and parcel as alleged of a nationwide conspiracy in which many of them are specifically mentioned as illustrations of the conspiracy itself. ... What, in fact, he [Nickerson] is doing is shifting from one side of a controversy to the other, and to make available the lnowledge and experience to which he has been 'exposed' as to the 'actual operation of these trade practices which he had acquired in eight years from the producers' side of these issues to that of une of their opponents." Master's Report, pp. 21-22.

43. In re Nickerson, 216 F.2d 920, 928 (2d Cir. 1954).

In Fisher Studio, Inc. v. Loew's, Inc., CCH TRade Rec. Rep. (1954 Trade Cas.) I 67725 (E.D.N.Y. 1954), an attorney was disqualified for representing interests adverse to the 
duty to former clients. It recognized that the fidelity duties inherent in Canon Six would be enforced in a proper case. ${ }^{44}$ On the other hand, it did not fully effectuate the policy underlying the protection of confidential information. The court suggested the possibility of utilizing an in camera hearing at which the former client would be required to prove that the attorney had received useful confidential information. ${ }^{45}$ But such a procedure would force the client to disclose confidential information which the attorney-client privilege is supposed to guard even from the trial judge. ${ }^{40}$ And if an attorney and client have sustained a professional relationship over a long period of time, many confidences reposed in the attorney may be forgotten by the client. Although the client may therefore be unable to prove the existence or specific nature of such communications, the information confided might give even a good faith attorney an advantage in the present litigation. ${ }^{47}$ Had the Second

clients of the firm which previously employed him. And although there was evidence that only some of the defendants were his former clients, the court disqualified the attorney as to all defendants. The decision was based on two factors. First, all the defendants were found to have acted more or less in concert and had conferred about their mutual interests. Secondly, the information obtained by the attorney was so interwoven that segregation was impractical. This rationale had been rejected previously in T.C. Theatre Corp. v. Warner Bros. Pictures, Inc., 125 F. Supp. 233 (S.D.N.Y. 1953), where the court limited disqualification to a single defendant although there was evidence inferring that a mutual interest existed among all the defendants in the past.

44. Nickerson argued that "the responsibility exemplified by the three paragraphs of Canon 6 is far broader and more restrictive than the mere duty not to divulge secrets (which is covered by Canon 37)." He described CANoN 6 as creating a fidelity duty but maintained that he was immune from the obligation because he was not a partner of the Dwight firm and hence no confidence was reposed in him. Bricf for Appellant, pp. 37-41. The petitioners, on the other hand, merged the CANoN 6 and 37 obligations drawing no distinction between them. Brief for Appellant, pp. 14-22. The Second Circuit accepted Nickerson's contention that CANons 6 and 37 should be considered independently. It re Nickerson, 216 F.2d 920, 924 (2d Cir. 1954). The facts of the instant case only necessitated applying the confidential information aspect of CANON 6 , but in no place was the fidelity duty negated.

45. In re Nickerson, 216 F.2d 920, 926 (2d Cir. 1954). But the court did not follow its suggestion in the principal case because of the complex issues of fact and law involved and the great burden which would have been necessary for the petitioners to sustain. The hearing idea was suggested as early as 1821. See Bricheno v. Thorpe, Jac. 200, 37 Eng. Rep. 864 (1821).

46. See note 10 sipra.

The court in T.C. Theatre Corp. v. Warner Bros. Pictures, Inc., 113 F. Supp. 265, 269 (S.D.N.Y. 1953), said in considering the same problem: "To compel the client to show, in addition to establishing that the subject of the present adverse representation is related to the former, the actual confidential matters previously entrusted to the attorncy and their possible value to the present client would tear aside the protective cloak drawn about the lawyer-client relationship. For the court to probe further and sift the confidences in fact revealed would require the disclosure of the very matters intended to be protected by the rule. It would defeat an important purpose of the rule of sccrecyto encourage clients fully and freely to make known to their attorncys all facts pertinent to their cause."

47. See T.C. Theatre Corp. v. Warner Bros. Pictures, Inc., 113 F. Supp. 265, 260 (S.D.N.Y. 1953), Note, 26 RockY Mr. L. Rev. 195 (1954). 
Circuit favored a broad application of the confidential information rule, it would have undoubtedly emphasized the special problems which arise in antitrust cases where the issue of conspiracy is the subject matter of the present as well as the previous representation. In order to insure the maximum flow of information to counsel it would seem necessary to allow defendants to disqualify any attorney who in the past had represented their co-conspirators in joint litigation. ${ }^{48}$ In the instant case, for example, Nickerson interviewed co-defendants of his firm's clients, and it may be inferred that in the interests of a joint defense he obtained information which would not have been given to opposing counsel or to a Government investigator. ${ }^{20}$ But apparently the Second Circuit did not feel that these considerations merit disqualification against such co-defendants in every case.

Several important public policies must be considered whenever a motion is made to disqualify an attorney for representing interests adverse to those of a former client. The policy of maintaining public confidence in the inviolate nature of confidential communications to attorneys and in the fidelity of attorneys to their clients' interests highlights only one aspect of the problem. Modern discovery procedures are based on the desirability of making available to litigants all the facts necessary for a full presentation of their case. $^{50}$ Privileged communications are immune from discovery because the harm involved in their suppression is believed to be outweighed by the utility of promoting free communication to counsel. ${ }^{61}$ But contemporary decisions have narrowed the area of privilege in the quest for complete disclosure of

48. This doctrine was suggested in Fisher Studio, Inc. v. Loew's, Inc, CCH Truve Rec. REP. (1954 Trade Cas.) ๆ 67725 (E.D.N.Y. 1954).

49. The Master found that during the Griffith litigation Nickerson interviewed $\mathrm{cm}$ ployees of Paramount, Fox, and Metro. Master's Report, p. 6. During the Schinc case Nickerson had interviews with office attorneys of the defendants. Id. at 9-10. During the Paramount case Nickerson collaborated with the other defendants against whom charges had been made. Ibid.

The Second Circuit failed to disqualify Nickerson as to six of the eleven defendants. See notes 31 and 38 supra. Four of these six were affliates, subsidiaries, or successors of those defendants against whom Nickerson was disqualified. Paramount Pictures Corporation and United Paramount Theatres, Inc. were both successors of Paramount Pictures, Inc. Brief for Appellee, p. 7, In re Nickerson, 216 F.2d 920 (2d Cir. 1954). Warner Bros. Circuit Management Corporation was a $100 \%$ subsidiary of Warner Bros. Pictures, Complaint, para. S, In re Nickerson, 1953 Trade Cas. If 67543 (S.D.N.Y. 1953). The Second Circuit apparently ignored the close corporate relationship among these alleged conspirators. This was also implicit in T.C. Theatre, Corp. v. Warner Bros. Pictures, Inc., 113 F. Supp. 265 (S.D.N.Y. 1953), where on relearing Judge Weinfeld implied that disqualification of the attorney against Paramount-Publix Corporation would not mean disqualification against its successor. The Second Circuit in the principal case found there was no parallel between the situation in T.C. Theatro, Corp. and Nichcrson. In re Nickerson, $216 \mathrm{~F} .2 \mathrm{~d}$ 920, 924-25 n.4 (2d Cir. 1954). But there is a parallel as to those defendants in Nickerson which are the corporate successors of the "group."

50. 4 Mcore, Federal Practice \ 26.02 (2d ed. 1950) ; McCoramick, Evivence § 3 (1954) ; Note, 62 Harv. L. Rev. 269 (1948).

51. MicCormick, op. cit. supra note 50, $\S \S 91,93 ; 8$ Wigrore, Endence $\S 2291$ (3d ed. 1940). 
all relevant information. ${ }^{52}$ A formulation of the attorney's ethical obligation which allows a former client to disqualify an attorney who has never received any confidential information useful in the present suit may unnecessarily restrict other parties from access to the legal talent most familiar with the facts of their case. Such a formulation may also unreasonably restrict access to attorneys specializing in technical areas of law. And in the antitrust field, where private actions are a means of enforcing national policy, these unnecessary restraints frustrate the implementation of public policy as well ats the vindication of private rights. ${ }^{53}$ Furthermore, the attorney's right to develop a special skill free from unwarranted limitations as to employment must be recognized. ${ }^{54}$ Since large areas of business endeavor are now controlled by a few corporations, an attorney has only a few prospective clients to serve in certain fields. ${ }^{55}$ Many young lawyers receive their initial training as associates of the large law firms which represent these corporations. If they are readily vulnerable to future disqualification by the firm's clients in these limited areas of practice, the consequence is a serious restriction upon their careers.

Ruling on a motion to disqualify an antitrust attorney who has switched from defending movie distributors to representing exhibitors requires the application of different principles than would ruling on a motion to disqualify a lawyer attempting to break a contract previously drafted by him. The Second Circuit was sound in restricting its decision in Nickerson to the type of case before it without negating the other standards implicit in the Canons of Professional Ethics. Unfortunately, it did not clearly articulate the basis for its holding. Unless courts delineate the various policy considerations motivating their decisions, precedents offer little guidance to attorneys seeking to fulfill their ethical obligations. ${ }^{56}$

52. See McCormick, op. cit. supra note 50, \& 81. Compare In re Selser, 15 N.J. 393, 105 A.2d 395 (1954), commented on in 77 N.J.L.J. 192, 196 (1954), wiih Hickman v. Taylor, 329 U.S. 495, 500-01, 507 (1947), discussed in 4 Moore, Federal Practice If 26.23[8] (2d ed. 1950).

53. Glen Coal Co. v. Dickinson Fuel Co., 72 F.2d 885, 889 (4th Cir. 1934); Fanchon \& Marco v. Paramount Pictures, Inc., 100 F. Supp. 84, 88 (S.D. Cal. 1951).

54. See Rakusen v. Ellis, [1912] 1 Ch. $831,839,841$ (C.A.). But cf. In re Nickerson, 216 F.2d 920, 926 (2d Cir. 1954).

55. For example, the court found in United States v. Paramount Pictures, Inc., 334 U.S. 131,167 (1948), that $70 \%$ of all the first run theatres in the 92 cities with populations over 100,000 were affiliated with one or more of the five major distributors. See F.T.C., Report on the Concentration of Productive Facilities (1947), for a representative coverage of the control of various areas of business activity by a few large corporations.

56. In the instant case, upon leaving the Dwight firm, Nickerson sought advice as to the extent of his obligation to his employer's clients. And he relied upon this advice in prosecuting the Consolidated complaint. Brief for Appellant, pp. 18-19. Similarly, other attorneys have unsuccessfully attempted to ascertain the extent of their cluty to former clients. See, e.g., Porter v. Huber, 68 F. Supp. 132 (W.D. Wash. 1946) ; In ro Boone, 83 Fed. 944, 963-64 (C.C.N.D. Cal. 1897); Sheffield v. State Bar, 22 Cal. 2d 627, 631-32, 140 P.2d 376, 379 (1943). 